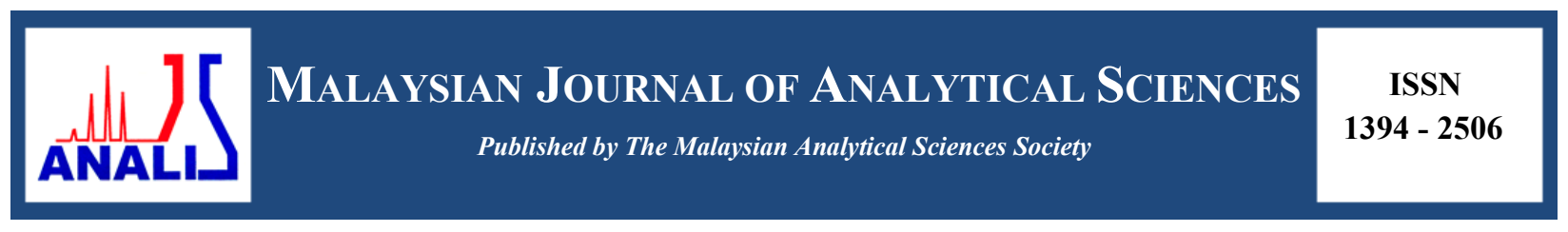

\title{
FLUORESCENCE AND EVAPORATIVE LIGHT SCATTERING HPLC PROFILING OF INTRACELLULAR ASPARAGINE ( $N$ )-LINKED OLIGOSACCHARIDES FROM Saccharomyces cerevisiae USING THE alg8 MUTANT
}

\author{
(Pemprofilan KCPT Pendarfluor dan Penyerakan Cahaya Sejatan Oligosakarida Terpaut- $(N)$ \\ Asparagina Intrasel daripada Saccharomyces cerevisiae Menggunakan Mutan alg8) \\ Iqbal Jalaludin ${ }^{1}$, Amirul Husna Sudin ${ }^{1}$, Ikram Mohd Said ${ }^{1,2}$, Kamalrul Azlan Azizan², Syarul Nataqain Baharum ${ }^{2}$, \\ Abdul Munir Abdul Murad ${ }^{3}$, Farah Diba Abu Bakar ${ }^{3}$, Nor Muhammad Mahadi ${ }^{4}$, Mark R. Wormald ${ }^{5}$, \\ Dominic S. Alonzi ${ }^{5}$, Mukram Mohamed Mackeen ${ }^{1,2 *}$ \\ ${ }^{I}$ School of Chemical Sciences and Food Technology \\ ${ }^{2}$ Institute of Systems Biology (INBIOSIS) \\ ${ }^{3}$ School of Biosciences and Biotechnology, Faculty of Science and Technology \\ Universiti Kebangsaan Malaysia, 43600 UKM Bangi, Selangor, Malaysia \\ ${ }^{4}$ Malaysia Genome Institute, \\ Jalan Bangi, 43000 Kajang, Selangor, Malaysia \\ ${ }^{5}$ Oxford Glycobiology Institute, \\ University of Oxford, South Parks Road, Oxford OX1 3QU, United Kingdom \\ *Corresponding author: mukram.mackeen@ukm.edu.my
}

Received: 21 June 2017; Accepted: 30 September 2017

\begin{abstract}
$\mathrm{N}$-glycans are biologically important oligosaccharides associated with the asparagine residue that may exist in protein-bound or unbound forms in all eukaryotes (including yeasts) and some bacteria. The- core structure of these oligosaccharides is based on the trimannosyl chitobiose structure resulting from cellular $N$-glycosylation. Preparative-scale amounts of these oligosaccharides are important for chemical, structural and functional studies due to their biological significance. Therefore, we explored a biochemical approach of oligosaccharide preparation using mutant-derived monoglucosylated lipid-linked oligosaccharides (LLOs) required for the assembly of $N$-linked glycoproteins and non-monoglucosylated free-oligosaccharides (fOSs) from misfolded $N$-linked glycoproteins using an $N$-glycosylation (alg) mutant of Saccharomyces cerevisiae. Oligosaccharide extracts of fOSs and LLOs from the alg 8 S. cerevisiae mutant lacking the $A L G 8$ gene were profiled using fluorescence- and evaporative light scattering-based HPLC. LLOs did not produce accumulated levels of the target mutant- related monoglucosylated $\left(\mathrm{Glc}_{1} \mathrm{Man}_{9} \mathrm{GlcNAc}_{2}\right)$ at $100 \mathrm{ml}$ scale. However, it was possible to detect truncated oligomannose (paucimannose) structures in the fOSs of the alg 8 mutant.
\end{abstract}

Keywords: $N$-linked glycosylation, $N$-glycans, Free oligosaccharides, Lipid-linked oligosaccharides, Saccharomyces cerevisiae

\section{Abstrak}

$N$-glikan merupakan oligosakarida yang penting dalam biologi yang bersekutu dengan residu asparagina yang hadir dalam keadaan terikat atau tidak terikat kepada protein dalam semua eukariot (termasuk yis) dan sesetengah bakteria. Struktur asas oligosakarida ini adalah berdasarkan struktur kitobiose trimanosa yang terhasil melalui pengglikosilan- $N$. Oligosakarida ini penting untuk kajian kimia, struktur dan fungsi disebabkan kepentingan biologinya. Oleh itu, kami telah mengkaji kaedah penyediaan oligosakarida dengan pendekatan biokimia menggunakan yis mutan (alg) Saccharomyces cerevisiae yang 


\section{Iqbal et al: FLUORESCENCE AND EVAPORATIVE LIGHT SCATTERING HPLC PROFILING OF INTRACELLULAR ASPARAGINE ( $N$ )-LINKED OLIGOSACCHARIDES FROM Saccharomyces cerevisiae USING THE alg8 MUTANT}

menghasilkan monoglukosa oligosakarida terpaut-lipid (LLO) yang diperlukan dalam pengumpulan glikoprotein terpaut- $N$ dan bukan-monoglukosa oligosakarida bebas (fOS) daripada glikoprotein terpaut- $N$ silap lipatan. Ekstrak oligosakarida fOS dan LLO daripada mutan alg8 S. cerevisiae tanpa gen $A L G 8$ telah diprofil menggunakan KCPT-pendarfluor dan pengesan penyerakan cahaya sejatan. LLO didapati tidak menghasilkan sebatian sasaran monoglukosa $\left(\mathrm{Glc}_{1} \mathrm{Man}_{9} \mathrm{GlcNAc}_{2}\right)$ berkaitan-mutan pada skala $100 \mathrm{ml}$. Walau bagaimanapun, struktur fOS oligomanosa terpangkas (pausimanosa) boleh dikesan daripada mutan alg8.

Kata kunci: pengglikosilan terpaut- $N$, $N$-glikan, Oligosakarida bebas, Oligosakarida terpaut-lipid, Saccharomyces cerevisiae

\section{Introduction}

Asparagine $(N)$-linked glycosylation is the most widespread form of modification found in secreted glycoproteins of all eukaryotes and some prokaryotes as part of the endoplasmic reticulum-associated degradation (ERAD) pathway [1]. These oligosaccharides are significant in various biological processes such as pathogenesis, development, fertility, protein biosynthesis and folding $[2,3]$. The biosynthesis of these naturally occurring oligosaccharides begins in the endoplasmic reticulum (ER) with the assistance of the lipid carrier dolichol-pyrophosphate (Dol-PP) to form a lipid-linked triglucosylated high-mannose type oligomannose $\mathrm{N}$-glycan. Subsequently, the Dol-PP lipidlinked oligosaccharide (LLO) is transferred co-translationally by oligosaccharyltransferase (OST) to an asparagine residue of a nascent polypeptide within $\mathrm{N}-\mathrm{X}-\mathrm{S} / \mathrm{T}$ sequence $(\mathrm{N}=$ asparagine, $\mathrm{X}=$ any amino acid except proline, $\mathrm{S}=$ serine, $\mathrm{T}=$ threonine) to produce $\mathrm{Glc}_{3} \mathrm{Man}_{9} \mathrm{GlcNAc}_{2} N$-linked glycoproteins in the ER. Triglucosylated $N$ glycoproteins are further processed by ER glucosidases I and II to generate monoglucosylated $\mathrm{Glc}_{1} \mathrm{Man}_{9} \mathrm{GlcNAc}_{2}$ and non-glucosylated $\mathrm{Man}_{9} \mathrm{GlcNAc}_{2}$ on partially folded proteins. Both these high-mannose type $\mathrm{N}$-glycan structures play a critical role in ERAD-controlled protein folding via interaction with the molecular chaperones calreticulin and calnexin [4]. After the initial phase of biosynthesis and protein folding quality control in the ER, these oligomannoses will be trimmed for either further (1) expansion in the Golgi with other mannose or non-mannose units such as galactose, galactosamine, glucosamine, xylose and sialic acid for secretion as glycoproteins or (2) truncation as protein unbound oligosaccharides in the cytosol and lysosome. Therefore, the lipid-linked and protein-unbound $\mathrm{N}$-glycans may represent a naturally occurring source for the scalable production of these oligosaccharides using a biochemical (mutant) approach as opposed to using chemical synthesis. In the ER, units of monosaccharides are linked to each other by the asparagine-linked glycosylation $(A L G) 1$ to 14 genes encoding $N$ glycosylation enzymes. Mutations involving $A L G$ genes will produce accumulation of the biosynthetically relevant $N$-glycan isomers. For example, absence of the $A L G 8$ gene that is responsible for the formation of $\mathrm{Glc}_{2} \mathrm{Man}_{9} \mathrm{GlcNAc}_{2}$ will result in the accumulation of the $\mathrm{Glc}_{1} \mathrm{Man}_{9} \mathrm{GlcNAc}_{2} N$-glycan LLO [5]. Therefore, this study explored the production of high-mannose type $\mathrm{N}$-glycans using the alg 8 mutant to obtain monoglucosylated and non-glucosylated $N$-glycans.

Among the many uses of obtaining sufficient quantity of $N$-glycans would be for structural/conformational studies such as to probe the critical role N-glycans play in the ERAD pathway [6]. Conformational studies of $N$-glycans is mainly based on NMR and molecular dynamics. The structural determination of glycans is beset by the limited spectral dispersion of 1D NMR $\left({ }^{1} \mathrm{H}\right.$ and ${ }^{13} \mathrm{C}$ nuclei). Although, using 2D NMR spectroscopy facilitates the process of resonance and linkage assignments, it is still tedious and time-consuming [7]. Isotope labelling especially ${ }^{13} \mathrm{C}$ and preparative-scale analysis of $\mathrm{N}$-glycans can significantly reduce analytical time and allow higher dimensional 3D and 4D NMR experiments to be carried out as routinely done in protein NMR. Additionally, $N$-glycans can be used as valuable analytical standards or as natural substrates for enzyme assays. The preparative-scale production of glycans is also beneficial for the synthesis of glycoconjugates. For example, glycans can be employed in bioorthogonal click chemistry to tag relevant protein substrates for proteomics analysis combining metabolic engineering and mass spectrometry. These tags facilitate the discovery of biomarkers involved in disease development through the screening of disease-related glycans and glycoproteins [8].

Preparative amounts of $\mathrm{N}$-glycans have been produced through total chemical synthesis, chemoenzymatic synthesis and isolation from natural sources $[9,10]$. Total chemical synthesis is by far the most challenging especially for larger and/or conjugated glycans such as glycoproteins and glycolipids. $N$-glycans obtained from $N$-linked glycoproteins and LLOs as well as fOS have been analysed in cells. However, the preparative scale production of $N$ glycans in previous reports have been complicated by the enzymatic (PNGase/Endo-H-treatment) or chemical (hydrazinolysis-based) release of $\mathrm{N}$-glycans from glycoproteins and tedious solvent-partitioning extractions steps 
for LLOs [11]. Commercially obtained PNGase F is expensive, and hydrazine is an explosive hazard for sugarrelease at the preparative-scale. Therefore, we investigated the use of LLOs and fOSs from a mutant Saccharomyces cerevisiae strain (alg8) as source of $\mathrm{N}$-glycans to: (1) obviate the need for sugar release and tedious solvent extraction and (2) obtain target $N$-glycans i.e the use of the alg8 mutant to obtain monoglucosylated structure(s) from LLOs and non-target $N$-glycans from fOSs.

\section{Reagents}

\section{Materials and Methods}

Yeast Nitrogen Base (YNB), selected amino acids, acid-washed glass beads, AG50W-X12 $\left(\mathrm{H}^{+}\right.$form), AG2-X8 $\left(\mathrm{Cl}^{-}\right.$ form) and DEAE-cellulose were kindly gifted by the Oxford Glycobiology Institute, University of Oxford. Water was obtained from The Pacific UP6 TKA system was used to obtain pure water. Other materials were purchased from major vendors such as Sigma and Merck unless stated otherwise.

\section{Yeast strains and culture conditions}

The Saccharomyces cerevisiae strains used in this study were BY4743 (MATa/ $\alpha$ his $3 \Delta 1 /$ his $3 \Delta 1$ leu2 $\Delta 0 /$ leu $2 \Delta 0$ met15 $\Delta 0 /$ MET15 lys2 $\Delta 0 /$ LYS2 ura3 $\Delta 0 /$ ura3 $\Delta 0$ ) and YOR067C BY4743 (MATa/ $\alpha$ his $3 \Delta 1 /$ his $3 \Delta 1$ leu2 $\Delta 0 /$ leu $2 \Delta 0$ met15 $\Delta 0$ /MET15 lys2 $\Delta 0 /$ LYS2 ura3 $\Delta 0 /$ ura3 $\Delta 0$ aalg8::kanMX4) from Dharmacon, GE Healthcare. Both yeast strains were grown aerobically in Yeast Nitrogen Base (YNB) medium $(100 \mathrm{ml})$ containing $2 \%(\mathrm{w} / \mathrm{v})$ glucose and $2 \%$ (w/v) selected-amino acids ( $4 \mathrm{mg} / \mathrm{ml}$ histidine, $4 \mathrm{mg} / \mathrm{ml}$ uracil, $4 \mathrm{mg} / \mathrm{ml}$ methionine and $12 \mathrm{mg} / \mathrm{ml}$ leucine) in a rotary shaker $(180 \mathrm{rpm})$ at $30^{\circ} \mathrm{C}$.

\section{Extraction of LLOs}

The LLOs were extracted using a previously described method [12]. The cell pellets were harvested by centrifugation $(2500 \mathrm{rpm} / 1200 \times \mathrm{g}, 8 \mathrm{~min}$; same parameters used for the rest of this protocol) and washed using phosphate-buffered saline (PBS) three times. Methanol $(10 \mathrm{ml})$ was added and the cells were transferred into glass tubes $(10 \mathrm{ml})$. Sonication was performed for 10 minutes using a water bath-type sonicator and dried under $\mathrm{N}_{2}$ gas. A chloroform-methanol $(2: 1 ; 10 \mathrm{ml})$ solution was added into the tubes, sonicated, vortexed, centrifuged and the supernatant discarded. The cells were resuspended in methanol again, sonicated for 10 minutes and dried under $\mathrm{N}_{2}$ gas. The chloroform-methanol extraction procedure was repeated, but this time using $10 \mathrm{ml}$ water and subsequently chloroform-methanol-water (CMW) $(10: 10: 3 ; 10 \mathrm{ml})$. The supernatants from the final centrifugation were collected for further LLO extraction. For LLO partial purification, each CMW extract was run through a DEAE-cellulose column pre-equilibrated with CMW. After sample loading, the column was washed using 10 bed volumes of CMW followed by 10 bed volumes of $3 \mathrm{mM}$ acetic acid in CMW. Elution was carried out using 10 bed volumes of 300 $\mathrm{mM} \mathrm{NH} \mathrm{H}_{4} \mathrm{OAc}$ in CMW. Chloroform (4.3 bed volumes) and water (1.2 bed volumes) were added into the collection tubes, vortexed and centrifuged which resulted in three phases. The upper layer was removed and the remaining layers (middle and lower) were dried using $\mathrm{N}_{2}$ gas. For oligosaccharides released from LLOs, $2 \mathrm{ml}$ of $0.1 \mathrm{~N} \mathrm{HCl}$ in $50 \%$ isopropanol was added into the dried samples, vortexed, incubated for 1 hour at $50{ }^{\circ} \mathrm{C}$ and dried under $\mathrm{N}_{2}$ gas. Butanol-saturated water $(1 \mathrm{ml})$ was added, vortexed. After that, $1 \mathrm{ml}$ of water-saturated butanol was added before centrifugation, and the lower phase was recovered after centrifugation and freeze-dried. The dried residues were resuspended in $1 \mathrm{ml}$ water to which $200 \mu \mathrm{l}$ of AG50W-X12 $\left(\mathrm{H}^{+}\right.$form) was added, vortexed, and centrifuged. The supernatant was collected and added to $200 \mu 1$ of AG2-X8 ( $\mathrm{Cl}^{-}$form) that was vortexed and then centrifuged. The oligosaccharides released from LLOs were obtained from the recovered supernatant.

\section{Extraction of fOSs}

fOSs were extracted by a previously described method [13]. Briefly, the harvest step was the same as LLO extraction, i.e. cells were recovered by centrifugation and the medium discarded. PBS buffer was added into the tube containing the cells and washed three times. Then, the cells were snap-frozen using liquid nitrogen for 10 seconds and thawed three times. One volume of lysis buffer (100 mM Tris- $\mathrm{HCl}$, pH 7.4 containing $4 \mathrm{mM} \mathrm{MgCl}_{2}$ ) and acid-washed glass beads were added into the tube, vortexed for 30 seconds (six times) and the cell debris removed by centrifugation. The supernatants were desalted by mixed-bed ion exchange column $(0.1 \mathrm{ml}$ of AG50W$\mathrm{X} 12\left[\mathrm{H}^{+}\right.$form $]$over $0.2 \mathrm{ml} \mathrm{AG8-X2}\left[\mathrm{Cl}^{-}\right.$form $]$), pre-equilibrated with $5 \times 1 \mathrm{ml}$ water, followed by loading and washing with $4 \times 1 \mathrm{ml}$. The eluate was collected for further analysis. 


\section{Iqbal et al: FLUORESCENCE AND EVAPORATIVE LIGHT SCATTERING HPLC PROFILING OF INTRACELLULAR ASPARAGINE ( $N$ )-LINKED OLIGOSACCHARIDES FROM Saccharomyces cerevisiae USING THE alg8 MUTANT}

\section{Phenol-sulfuric acid assay}

The concentration of oligosaccharides in the extracted fOS samples were determined using the microtiter phenolsulfuric acid assay (PSA) instead of the conventional tube-based assay [14]. Three types of samples were prepared; blank, standard and samples. The blank was the solvent used for dissolving the standards and samples. A series of known glucose standard concentrations ranging from 0.05 to $1.0 \mathrm{mg} / \mathrm{ml}$ was prepared. For each $50 \mu 1$ sample, 150 $\mu \mathrm{l}$ of concentrated sulfuric acid was added rapidly into a well of a 96-well microplate for maximum mixing. Immediately after acid-mixing, $30 \mu 1$ of $5 \%$ phenol was added followed by incubation at $90{ }^{\circ} \mathrm{C}$ for 5 minutes using a water bath. The plate was floated carefully to avoid any sample leakage. The plate was cooled for a few minutes and wiped dry to measure the absorbance at $490 \mathrm{~nm}\left(A_{490 \mathrm{~nm}}\right)$ using a microplate reader.

\section{Carbohydrate fluorescence labelling}

The carbohydrates were labelled with 2-anthranilic acid (2-AA) as previously described [15]. For the labelling reaction, $30 \mathrm{mg}$ of 2 -AA was dissolved in $1 \mathrm{ml}$ methanol containing $4 \%(\mathrm{w} / \mathrm{v})$ sodium acetate trihydrate and $2 \%$ $(\mathrm{w} / \mathrm{v})$ boric acid, followed by the addition of $45 \mathrm{mg}$ sodium cyanoborohydride addition. Labelling reagent $(80 \mu \mathrm{l})$ was added to each sample $(30 \mu \mathrm{l})$ and mixed well before incubation in a heating block for $80{ }^{\circ} \mathrm{C}$ for $45-60$ minutes. The reaction was cooled at room temperature and $1 \mathrm{ml}$ of acetonitrile/water $(97: 3, \mathrm{v} / \mathrm{v})$ was added. The labelled samples were then further purified using Discovery DPA-6S column pre-equilibrated with 1 column volume of acetonitrile water. The column was washed with $95 \%$ acetonitrile after sample loading and eluted with $2 \times 0.75 \mathrm{ml}$ of water which was collected.

\section{Carbohydrate analysis by HPLC-ELSD}

The unlabelled samples were analysed by HPLC (Dionex UltiMate 3000 LC System) using an XBridge ${ }^{\mathrm{TM}}$ amide column, $3.5 \mu \mathrm{m} ; 4.6 \times 250 \mathrm{~mm}$ (Waters) coupled to an evaporative light scattering detector (ELSD) PS-ELS 2100 Ice (Polymer Laboratories) connected to nitrogen generator. The detector was set as follows: vaporisation temperature $=55^{\circ} \mathrm{C}$; gas flow $=1.6 \mathrm{slm}$ (standard litre per minute); light intensity $=100 \%$; gain $=1.0$; nebulisation $=30{ }^{\circ} \mathrm{C}$. Solvent A contained $20 \% 100 \mathrm{mM}$ ammonium acetate, $\mathrm{pH} 3.85$, in Milli-Q water and $80 \%$ acetonitrile. Solvent B contained 20\% $100 \mathrm{mM}$ ammonium acetate, $\mathrm{pH} 3.85$, in Milli-Q water, $60 \%$ Milli-Q water, and $20 \%$ acetonitrile. Gradient conditions for carbohydrate analysis were as follows: time $=0 \min (t=0), 86 \%$ solvent $\mathrm{A}(0.8$ $\mathrm{ml} / \mathrm{min}) ; \mathrm{t}=6,86 \%$ solvent A $(0.8 \mathrm{ml} / \mathrm{min}) ; \mathrm{t}=35,54.7 \%$ solvent $\mathrm{A}(0.8 \mathrm{ml} / \mathrm{min}) ; \mathrm{t}=37,5 \%$ solvent A $(0.8$ $\mathrm{ml} / \mathrm{min}) ; \mathrm{t}=39,5 \%$ solvent $\mathrm{A}(0.8 \mathrm{ml} / \mathrm{min}) ; \mathrm{t}=41,86 \%$ solvent $\mathrm{A}(0.8 \mathrm{ml} / \mathrm{min}) ; \mathrm{t}=60,86 \%$ solvent $\mathrm{A}(0.8 \mathrm{ml} / \mathrm{min})$ [15]. Samples were dissolved in Milli-Q water/acetonitrile $(2: 8, \mathrm{v} / \mathrm{v})$ and injected using an autosampler $(50 \mu \mathrm{l}$ per injection).

\section{Carbohydrate analysis by HPLC-FD}

The 2-AA labelled samples were kindly analysed by the Oxford Glycobiology Institute, University of Oxford, United Kingdom using normal phase-HPLC with a $4.6 \mathrm{~mm} \times 250 \mathrm{~mm}$ TSK gel-Amide 80 column $(5 \mu \mathrm{m})$ (Anachem, Luton, Beds, U.K) as described previously [15]. The chromatography system consisted of Waters Alliance 2695 separations module and an in-line Waters 474 fluorescence detector (FD) set at Ex $\lambda 360 \mathrm{~nm}$ and Em $\lambda$ $425 \mathrm{~nm}$. Solvent A and B were prepared as described above for the HPLC-ELSD analysis. Gradient conditions for carbohydrate analysis were as follows: time $=0 \min (\mathrm{t}=0), 86 \%$ solvent $\mathrm{A}(0.8 \mathrm{ml} / \mathrm{min}) ; \mathrm{t}=6,86 \%$ solvent $\mathrm{A}(0.8$ $\mathrm{ml} / \mathrm{min}) ; \mathrm{t}=35,54.7 \%$ solvent A $(0.8 \mathrm{ml} / \mathrm{min}) ; \mathrm{t}=37,5 \%$ solvent $\mathrm{A}(1 \mathrm{ml} / \mathrm{min}) ; \mathrm{t}=39,5 \%$ solvent A $(1 \mathrm{ml} / \mathrm{min}) ; \mathrm{t}$ $=41,86 \%$ solvent $\mathrm{A}(1 \mathrm{ml} / \mathrm{min})$. Samples were injected in Milli-Q water/acetonitrile $(2: 8, \mathrm{v} / \mathrm{v})$.

\section{Yeasts growth}

\section{Results and Discussion}

Monoglucosylated structures of LLOs were expected to be accumulated with the deletion of the $A L G 8$ gene in the LLO biosynthesis pathway. However, fOS was produced through deglycosylation of misfolded glycoprotein by the enzyme PNGase F. This enzyme is known to be regulated in a growth-dependent manner [13]. Under standard culture and laboratory conditions, wild type $S$. cerevisiae reaches the stationary phase, approximately, after 6 days [16]. Based on this, larger fOSs $\left(\mathrm{Man}_{7-9} \mathrm{GlcNAc}_{2}\right)$ were usually observed at the exponential phase and the presence of these glycans were much reduced after six days of culture [13]. Thus, we generated a growth curve for the parental and mutant yeast strains to harvest cells in the appropriate growth phase. Figure 1 shows the growth pattern of the parental and mutant strains of the yeasts for 4 days. The growth curve intercepted each other after 3 days of 
culture the parental strain almost reached the stationary phase by day 3 . However, mutant strain still increased after the third day and was expected to reach the stationary phase after 6 days as described previously. Hence, we decided to harvest the cells after 2 days because both yeasts showed a steady increase in growth and the larger glycans are accumulated in this phase.

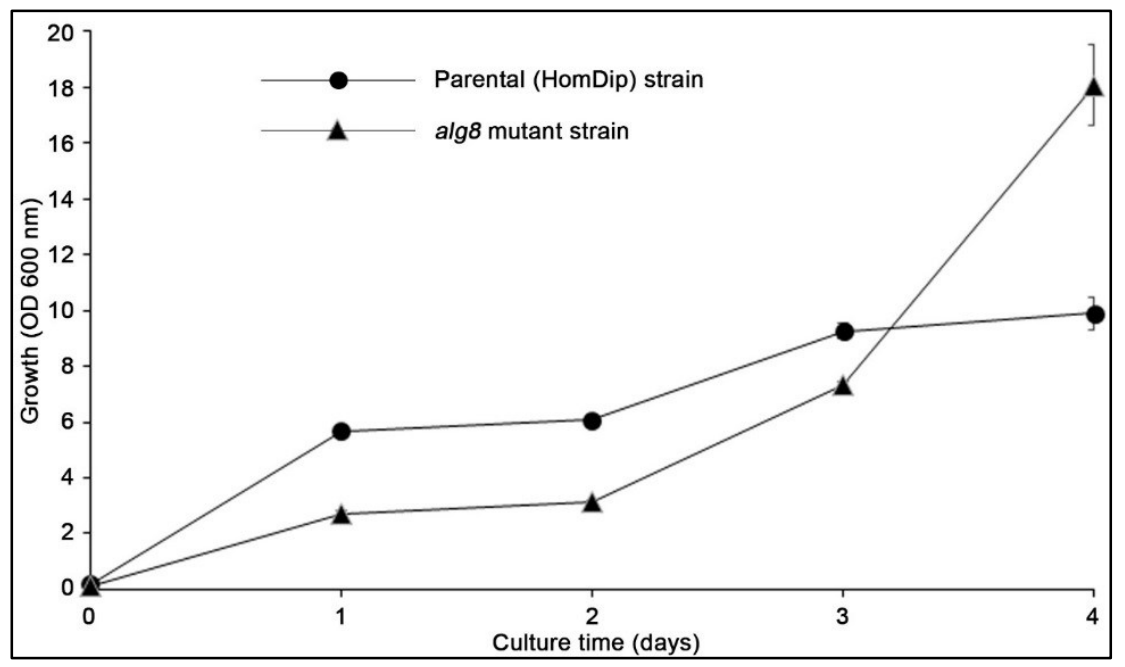

Figure 1. The growth curve of parental (HomDip) and alg8 mutant strains

\section{Total concentration of carbohydrates in fOS extracts}

The total concentration of carbohydrates was determined using the PSA assay. A standard curve for quantification was generated using glucose. The linear equation generated from the standard curve shown to calculate sample concentrations was $\mathrm{y}=1.115 \mathrm{x}-0.008\left(R^{2}=0.995\right)$ (Figure 2). The total oligosaccharide content of only the fOS samples were determined due to the negligible amounts of LLO extracted that were too little to be weighed $(<1 \mathrm{mg})$ and detection of very weak peaks by fluorescence-based HPLC. Comparison of between the fOS crude extracts of the parent and mutant strains showed that the concentration of carbohydrates was higher in the parent strain than the mutant strain. The values were also comparable to levels to the difference in OD readings measuring growth.

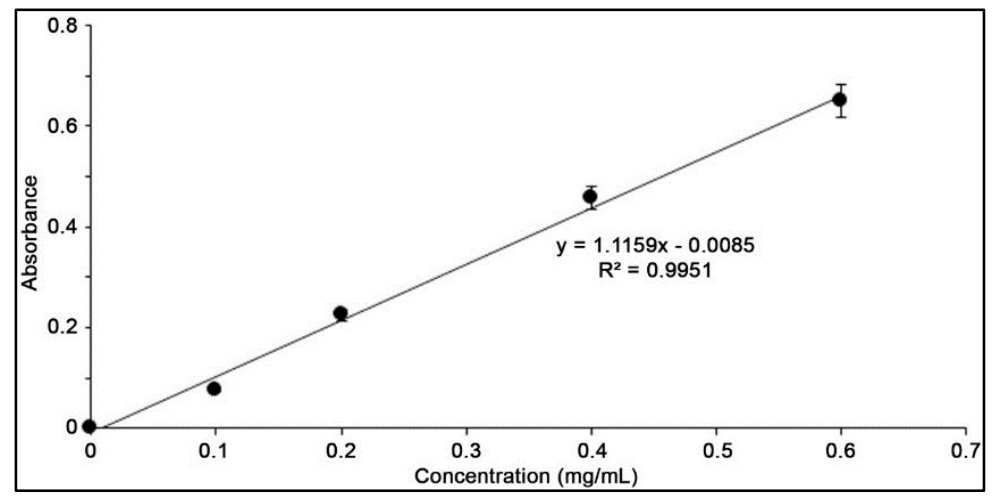

Figure 2. Standard curve of glucose for total carbohydrate content determination (PSA method) 


\section{Iqbal et al: FLUORESCENCE AND EVAPORATIVE LIGHT SCATTERING HPLC PROFILING OF INTRACELLULAR ASPARAGINE ( $N$ )-LINKED OLIGOSACCHARIDES FROM Saccharomyces cerevisiae USING THE alg8 MUTANT}

Table 1. Crude samples total carbohydrate concentration of parental and mutant strains

\begin{tabular}{lc}
\hline Samples & $\begin{array}{c}\text { Concentration } \\
\text { (mg/ml of cell lysate) }\end{array}$ \\
\hline Parent strain (crude sample) & 2.83 \\
alg8 mutant strain (crude sample) & 2.06 \\
\hline
\end{tabular}

\section{Analysis of LLOs and fOSs with HPLC-ELSD and HPLC-FD}

HPLC analysis on the samples was carried out using ELSD and FD. The former mode of detection was universal and less sensitive whereas the latter was selective and highly sensitive. The dextran molecular weight ladder standard $(0.1 \mathrm{mg} / \mathrm{ml})$, LLOs and fOS extracted from parental and alg8 mutant strains were analysed and shown in Figures $3-6$. The HPLC-ELSD and FD chromatograms of the dextran ladder demonstrated good separation of peaks representing carbohydrates (glucose unit: GU) of difference sizes (ELSD: GU1 to GU12; and FD: GU1GU13). Some of the HPLC-ELSD peaks were broad and slightly spilt. This is most probably a result of different configurations $(\alpha / \beta$ isomers) of the unlabeled sugar unit at the reducing end [17]. The 2AA-labelled fOS FD chromatogram showed a more complex profile of peaks than the unlabeled fOS ELSD chromatogram (Figures 3 and 5). fOS extract peaks appearing at lower retention times corresponding to $\leq$ GU3 were abundant in both the ELSD and FD chromatograms. In the FD chromatogram, these peaks were present at extremely high intensities exceeding the detection threshold of fluorescent detection $(\geq 10000 \mathrm{mV})$ (data not shown). The profiles suggested that ELS detection was not suitable (insensitive) for carbohydrate profiling on this scale of culture compared to fluorescence detection.

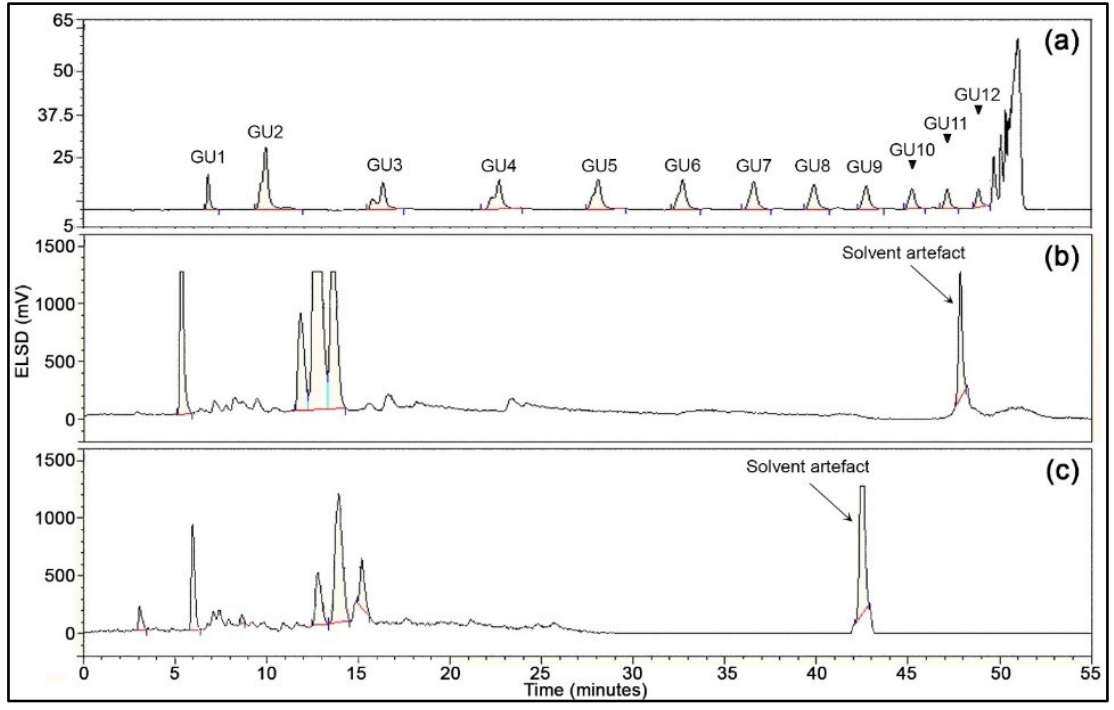

Figure 3. HPLC-ELSD analysis of (a) standard dextran and unlabeled fOS from (b) parental and (c) mutant strains

The major peaks in the HPLC profiles were more abundant in the parental strain. The common present in parent and mutant) abundant peaks present in both the parent and mutant may correspond to $\beta$-glucans associated with the cell wall of yeast have been extracted in fOS samples [18]. HPLC peaks were assigned using the glucose unit analysis method via the calculation of GU values calibrated to the dextran mixture standard for comparison to the values of known structures (Figure 6 and 7) [19,20]. Based on this approach, two additional and abundant peaks with lower GU values were present in the alg8 mutant. The additional peaks in the mutant had low GU values at $5.30\left(\mathrm{R}_{\mathrm{t}}=\right.$ 23.0) and $6.47\left(\mathrm{R}_{\mathrm{t}}=27.7\right)$ corresponding to the paucimannose $N$-glycans $\mathrm{Man}_{5} \mathrm{GlcNAc}_{2}$ and $\mathrm{Man}_{6} \mathrm{GlcNAc}_{2}$, respectively (Figure 5) $[19,20]$. This is due to the truncation of free monoglucosylated $\mathrm{Man}_{9} \mathrm{GlcNAc}_{2}$ from 
misfolded $N$-linked glycoproteins by glucosidse II and mannosidases in the ERAD pathway. For the two reported peaks, $\mathrm{Man}_{6} \mathrm{GlcNAc}_{2}$ was trimmed by $\alpha-1,2$-mannosidase in ER to produce $\mathrm{Man}_{5} \mathrm{GlcNAc}_{2}$. In addition, the known absence of Endoglycosidase-H (Endo-H) in S. cerevisiae suggested that the glycan structures should be present with two GlcNAc units instead of one because, under normal circumstances, the presence of Endo-H will cleave chitobiose [21]. Our results show that the accumulation of fOSs from the lysate of alg8 S. cerevisiae mutant was more abundant than LLOs at the same scale of culture. Although LLOs did not show accumulation of the target $N$ glycan $\mathrm{Glc}_{1} \mathrm{Man}_{9} \mathrm{GlcNAc}_{2}$, elevated levels of truncated oligomannose (paucimannose) $N$-glycans $\mathrm{Man}_{5} \mathrm{GlcNAc}_{2}$ and $\mathrm{Man}_{6} \mathrm{GlcNAc}_{2}$ were detected in fOSs using the alg8 mutant.

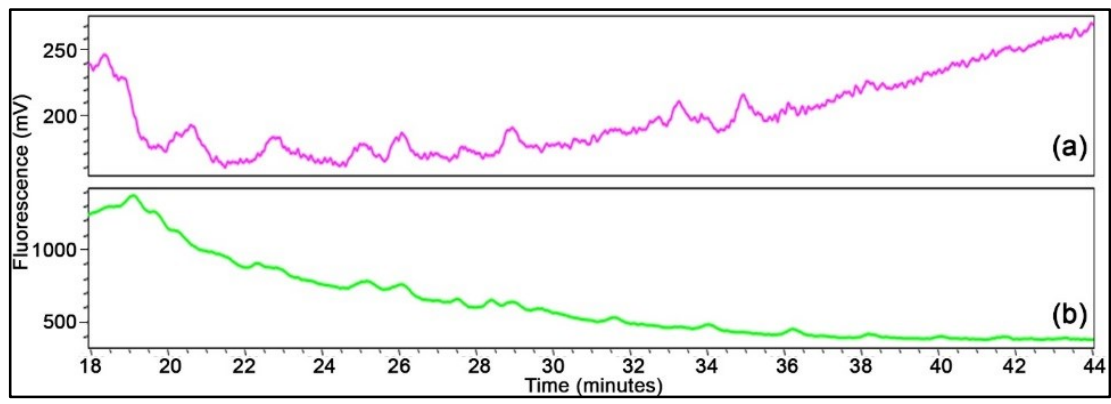

Figure 4. HPLC-FD analysis of 2-AA labelled LLOs from (a) parental and (b) mutant strains

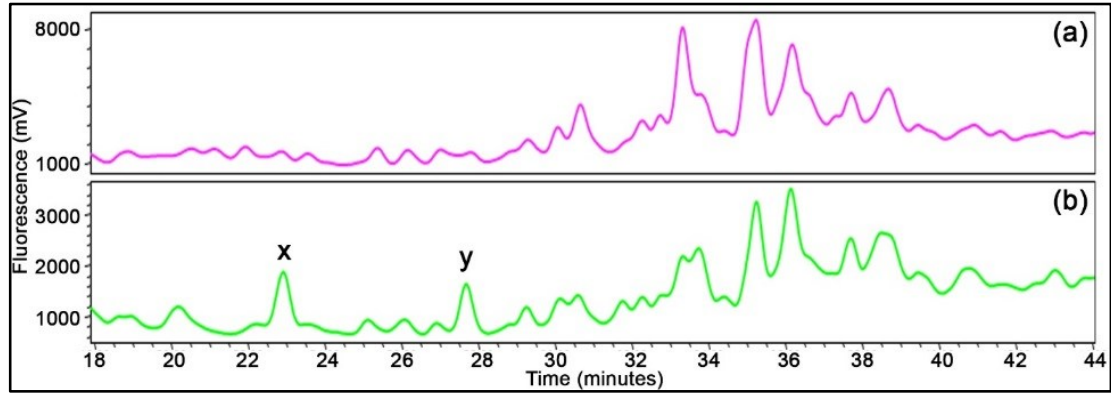

Figure 5. HPLC-FD analysis of 2-AA labelled fOS from (a) parental and (b) alg8 mutant strains; $\mathrm{x}=\mathrm{Man}_{5} \mathrm{GlcNAc}_{2}$ and $\mathrm{y}=\mathrm{Man}_{6} \mathrm{GlcNAc}_{2}$

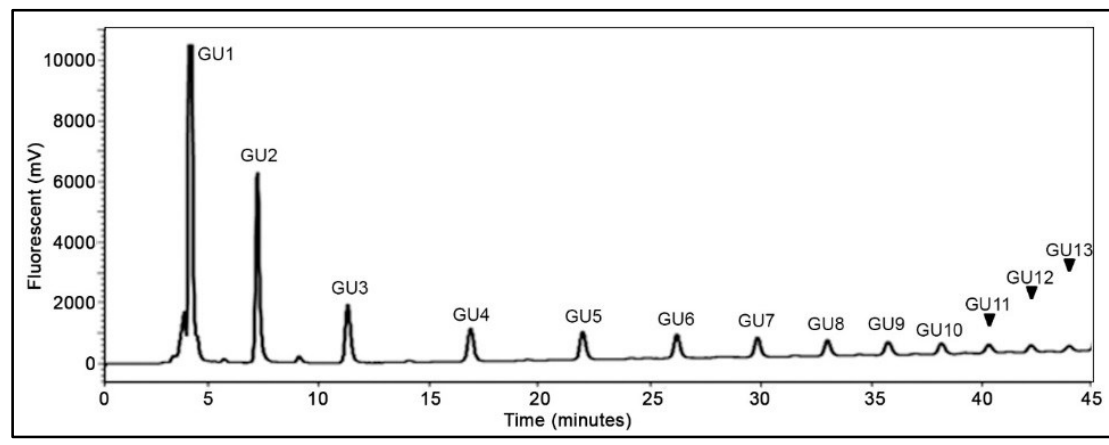

Figure 6. Normal phase-HPLC separation of 2-AA-Dextran with detection by fluorescence 


\section{Iqbal et al: FLUORESCENCE AND EVAPORATIVE LIGHT SCATTERING HPLC PROFILING OF INTRACELLULAR ASPARAGINE ( $N$ )-LINKED OLIGOSACCHARIDES FROM Saccharomyces cerevisiae USING THE alg8 MUTANT}

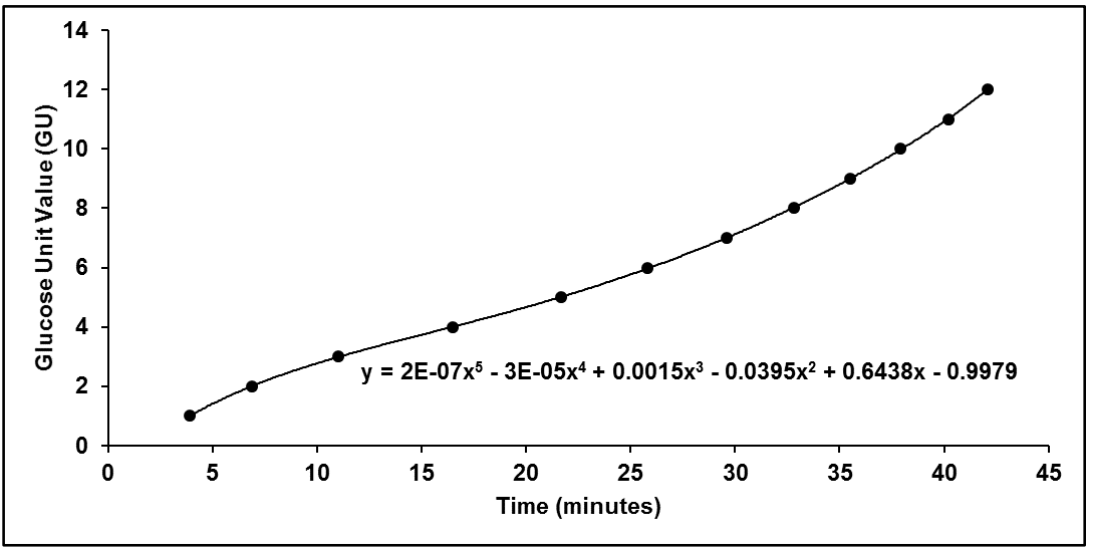

Figure 7. $5^{\text {th }}$ order calibration curve generated from 2-AA-dextran profile for glucose unit (GU) value determination based on HPLC retention times

\section{Conclusions}

fOSs from S. cerevisiae afforded higher amounts of oligosaccharides than LLO at the same scale of culture $(100 \mathrm{ml})$. Accumulation of the monoglucosylated $\mathrm{Glc}_{1} \mathrm{Man}_{9} \mathrm{GlcNAc}_{1}$ and/or its mannose-truncated forms was not observed in the LLOs of the alg8 S. cerevisiae mutant. However, accumulation of truncated oligomannoses (paucimannoses) Man ${ }_{5} \mathrm{GlcNAc}_{2}$ and $\mathrm{Man}_{6} \mathrm{GlcNAc}_{2}$ was only observed in the fOS extract of the same mutant.

\section{Acknowledgements}

This work was supported by the Ministry of Higher Education under Grant ERGS/1/2013/STG01/UKM/01/1 and the Malaysia Genome Institute, Ministry of Science, Technology and Innovation Malaysia (MOSTI) under grant 02 05-20- SF0007. The authors also wish to thank the School of Chemical Sciences and Food Technology, School of Bioscience and Biotechnology, Institute of Systems Biology, Universiti Kebangsaan Malaysia and the Oxford Glycobiology Institute, University of Oxford for access to their facilities and technical support.

\section{References}

1. Aebi, M. (2013). N-linked protein glycosylation in the ER. Biochimica et Biophysica Acta - Molecular Cell Research, 1833: 2430 - 2437.

2. Cheon, Y. and Kim, C. (2015). Impact of glycosylation on the unimpaired functions of the sperm. Clinical and Experimental Reproductive Medicine, $42: 77$ - 85.

3. Ferris, S. P., Kodali, V. K. and Kaufman, R. J. (2014). Glycoprotein folding and quality-control mechanisms in protein-folding diseases. Disease Models \& Mechanisms, 7: 331 - 341.

4. $\mathrm{Xu}, \mathrm{C}$. and $\mathrm{Ng} \mathrm{D}$. T. W. (2015). Glycosylation-directed quality control of protein folding. Nature Reviews Molecular Cell Biology, 16: 742 - 752.

5. Runge, K. W. and Robbins, P. W. (1986). A new yeast mutation in the glucosylation steps of the asparaginelinked glycosylation pathway. Formation of a novel asparagine-linked oligosaccharide containing two glucose residues. Journal of Biological Chemistry, 261: 15582 - 15590.

6. Mackeen, M. M., Almond, A., Deschamps, M., Cumpstey, I., Fairbanks, A. J., Tsang, C., Rudd, P. M., Butters, T. D., Dwek, R. A. and Wormald, M. R. (2009). The conformational properties of the $\mathrm{Glc}_{3}$ Man unit suggest conformational biasing within the chaperone-assisted glycoprotein folding pathway. Journal of Molecular Biology, 387: 335 - 347.

7. Lundborg, M. and Widmalm, G. (2011). Structural analysis of glycans by NMR chemical shift prediction. Analytical Chemistry, 83: $1514-1517$.

8. Zhang, X. and Zhang, Y. (2013). Applications of azide-based bioorthogonal click chemistry in glycobiology. Molecules, 18: $7145-7159$. 
9. Kelleher, D. J., Karaoglu, D. and Gilmore, R. (2001). Large-scale isolation of dolichol-linked oligosaccharides with homogeneous oligosaccharide structures: Determination of steady-state dolichol-linked oligosaccharide compositions. Glycobiology, 11: $321-333$.

10. Verostek, M. F., Lubowski, C. and Trimble, R. B. (2000). Selective organic precipitation/extraction of released $N$-glycans following large-scale enzymatic deglycosylation of glycoproteins. Analytical Biochemistry, 278: 111 $-122$.

11. Roth, Z., Yehezkel, G. and Khalaila, I. (2012). Identification and quantification of protein glycosylation. International Journal of Carbohydrate Chemistry, 2012: 1 - 10.

12. Gao, N. (2005). Fluorophore-assisted carbohydrate electrophoresis: a sensitive and accurate method for the direct analysis of dolichol pyrophosphate-linked oligosaccharides in cell cultures and tissues. Methods, 35: 323 $-327$.

13. Chantret, I., Kodali, V. P., Lahmouich, C., Harvey, D. J. and Moore, S. E. H. (2011). Endoplasmic reticulumassociated degradation (ERAD) and free oligosaccharide generation in Saccharomyces cerevisiae. Journal of Biological Chemistry, 286: 41786 - 41800.

14. Masuko, T., Minami, A., Iwasaki, N., Majima, T., Nishimura, S. I. and Lee, Y. C. (2005). Carbohydrate analysis by a phenol-sulfuric acid method in microplate format. Analytical Biochemistry, 339: 69-72.

15. Neville, D. C. A., Coquard, V., Priestman, D. A., te Vruchte, D. J. M., Sillence, D. J., Dwek, R. A., Platt, F. M. and Butters, T. D. (2004). Analysis of fluorescently labeled glycosphingolipid-derived oligosaccharides following ceramide glycanase digestion and anthranilic acid labeling. Analytical Biochemistry, 331: 275 - 282.

16. Gray, J. V., Petsko, G. A., Johnston, G. C., Ringe, D., Singer, R. A. and Werner-Washburne, M. (2004). Sleeping beauty: quiescence in Saccharomyces cerevisiae. Microbiology and Molecular Biology Reviews, 68: $187-206$.

17. Hossain, T. J., Harada, Y., Hirayama, H., Tomotake, H., Seko, A. and Suzuki, T. (2016). Structural analysis of free $N$-glycans in $\alpha$-glucosidase mutants of Saccharomyces cerevisiae: Lack of the evidence for the occurrence of catabolic $\alpha$-glucosidase acting on the $N$-glycans. PLoS One, 11: e0151891.

18. Hirayama, H., Seino, J., Kitajima, T., Jigami, Y. and Suzuki, T. (2010). Free oligosaccharides to monitor glycoprotein endoplasmic reticulum-associated degradation in Saccharomyces cerevisiae. Journal of Biological Chemistry, 285: 12390 - 12404.

19. Alonzi, D. S., Neville, D. C. A., Lachmann, R. H., Dwek, R. A. and Butters, T. D. (2008). Glucosylated free oligosaccharides are biomarkers of endoplasmic-reticulum alpha-glucosidase inhibition. Biochemical Journal, 409: $571-580$.

20. Guile, G. R., Rudd, P. M., Wing, D. R., Prime, S. B. and Dwek, R. A (1996). A rapid high-resolution highperformance liquid chromatographic method for separating glycan mixtures and analyzing oligosaccharide profiles. Analytical Biochemistry, 240: $210-226$.

21. Murakami, S., Takaoka, Y., Ashida, H., Yamamoto, K., Narimatsu, H. and Chiba, Y. (2013). Identification and characterization of endo- $\beta-N$-acetylglucosaminidase from methylotrophic yeast Ogataea minuta. Glycobiology, 23: $736-744$. 